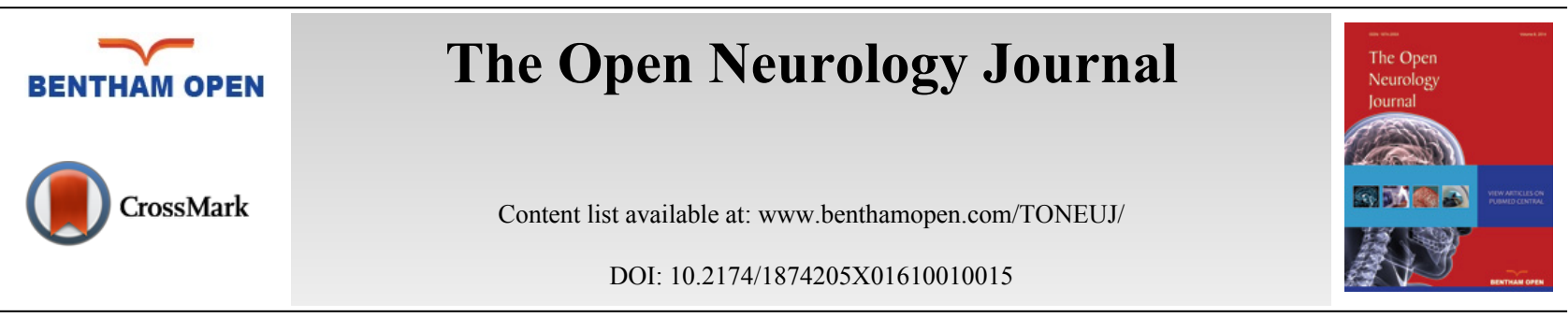

\title{
Nationwide Incidence of Normal Pressure Hydrocephalus (NPH) Assessed by Insurance Claim Data in Germany
}

\author{
Johannes Lemcke ${ }^{1, *}$, Dirk Stengel ${ }^{2,3}$, Florian Stockhammer ${ }^{4}$, Claas Güthoff ${ }^{2}$, Veit Rohde ${ }^{4}$ and Ullrich \\ Meier $^{1}$ \\ ${ }^{I}$ Department of Neurosurgery, Unfallkrankenhaus Berlin, Germany \\ ${ }^{2}$ Center for Clinical Research, Department of Trauma and Orthopedic Surgery, Unfallkrankenhaus Berlin, Germany \\ ${ }^{3}$ Julius Wolff Institute, Charité Medical University Center, Berlin, Germany \\ ${ }^{4}$ Department of Neurosurgery, Georg August University of Göttingen, Germany
}

Received: November 11, 2015

Revised: February 8, 2016

Accepted: March 2, 2016

\section{Abstract:}

Background:

The purpose of this study is to investigate the epidemiology of the idiopathic normal pressure hydrocephalus (iNPH) in Germany.

\section{Methods:}

The database of the nationwide Barmer Health Insurance was queried for specific combinations of corresponding International Classification of Diseases, Ninth Revision (ICD-9) codes and OPS codes (German modification of the ICPM and official classification of surgical procedures) in order to assess the number of patients treated for iNPH and the number surgical procedures associated with the disease in a 10 years period between 2003 and 2012.

\section{Results:}

Between 2003 and 2012, the incidence of iNPH increased from zero to 1.36/100.000/year.

\section{Conclusion:}

This is the first population-based epidemiologic study on iNPH in Germany covering a ten year period.

Keywords: Epidemiology, Incidence, Normal pressure hydrocephalus, Shunt surgery.

\section{INTRODUCTION}

Idiopathic Normal Pressure Hydrocephalus (iNPH) remains the currently only curable form of dementia. The treatment of choice is surgical drainage by ventriculo-peritoneal shunting. Previous pathophysiological concepts explaining iNPH as a mismatch between production and resorption of cerebrospinal fluid (CSF) were recently challenged by the vascular sclerosis theory $[1,2]$. Sclerotic vessels cannot transform pulsatile into laminar blood flows. Thus, unabated intracranial systolic peaks may press the periventricular brain to the ventricular volume and subsequently cause mechanical damage of ependymal cells.

Better understanding of the pathophysiology of iNPH together with advances in brain imaging prompted interest in this condition by health care providers and policy makers. The epidemiology of iNPH in the industrialized countries, specifically the prevalence of the disease among all forms of dementia, is, however, difficult to estimate. Data from

\footnotetext{
* Address correspondence to this author at the Department of Neurosurgery, Unfallkrankenhaus Berlin, Warener Str. 7, 12683 Berlin, Germany; Tel: ++49 305681 37016; Fax: ++49 305681 3703; E-mails: johannes.lemcke@ukb.de, johannes.lemcke@web.de
} 
Vestfold County in Norway with a stable population of 220000 inhabitants suggest a prevalence of probable iNPH of 21.9 and an incidence of 5.5 per 100,000 [2], with up to $1.5 / 100,000$ patients undergoing surgery annually [3].

In Germany, researchers interested in the epidemiology of iNPH often refer to data from the cross-sectional Starnberg study, a door-to-door survey conducted in two rural villages in the Isar valley in Bavaria, Southern Germany, almost two decades ago. The study was originally intended to study Parkinsonism, not iNPH, and may thus suffer from substantial misclassification bias [4]. The researchers claimed a prevalence of iNPH-related gait disorders of $4 / 982$ $(0.41 \%)$. This estimate is not representative for the German population either.

Compulsory health insurance in Germany is covered by various insurance bodies and companies. The Barmer GEK is one of the largest statutory insurance companies and provides health insurance for 8.7 million people (about $10 \%$ of the entire German population, see http://www.barmer-gek.de). German data safety and protection rules are very strict and limit research activities based on routine administrative hospital and discharge information.

Yet, Barmer granted these researchers access to anonymized datasets to answer the following key questions

1. What is the prevalence of iNPH amongst all (Barmer-insured) subjects with signs and symptoms of dementia?

2. What is the annual incidence $(\mathrm{n} / 100,000)$ of iNPH in Barmer-insured subjects and Barmer-insured subjects with newly diagnosed dementia?

\section{MATERIAL AND METHODS}

\section{Data Source}

Barmer allowed the investigators to search several combinations of hospital diagnoses according to ICD-9 (International Classification of Diseases, Ninth Revision) and OPS codes (German modification of the International Classification of Procedures in Medicine [ICPM], and official classification of surgical procedures). Due to legal restrictions, any data allowing for identifying individual patients, medical institutions or physicians in any form were kept anonymous. The number of individuals insured by Barmer between 2003 and 2012 ranged from 6.8 to 8.7 million. Cumulative data from all Barmer-covered subjects discharged from hospital care between 2003 and 2012 were included in the study.

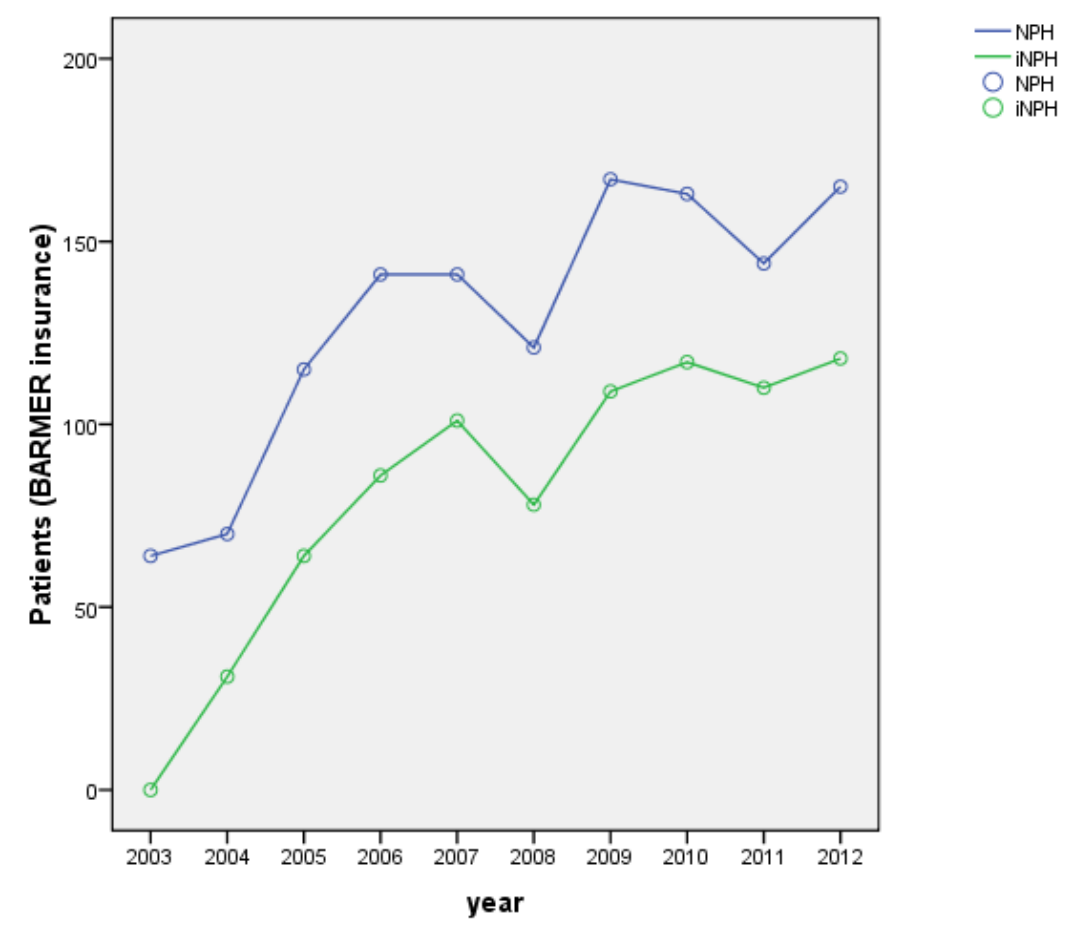

Fig. (1). The line represents the number of (i) NPH patients who underwent shunt surgery among the BARMER GEK insurants between 2003 and 2012, representing the incidence of NPH. 


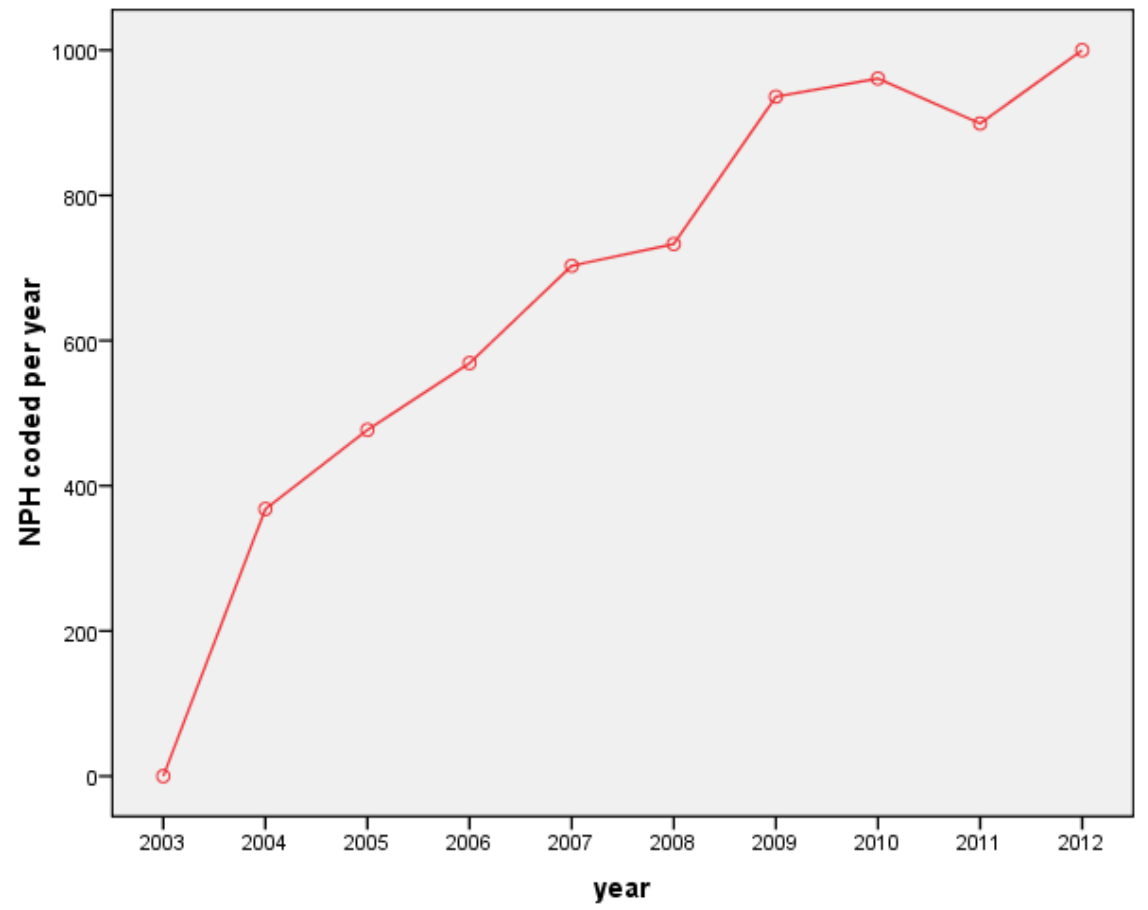

Fig. (2). The line represents the frequency of coded NPH among the Barmer insurants between 2003 and 2012, representing the prevalence of NPH.

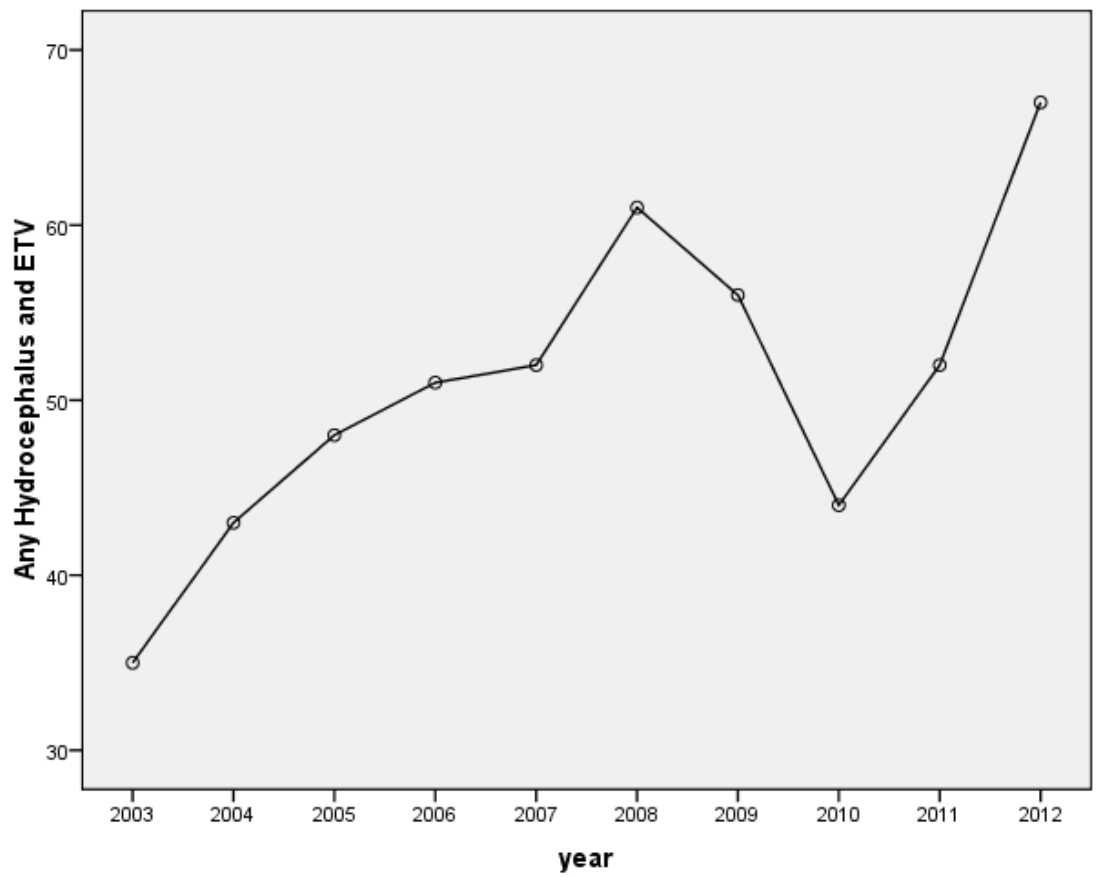

Fig. (3). Frequency of ETVs in the BARMER population between 2003 and 2012.

\section{Query Logic}

Based on literature data and own experience and expertise, the authors developed a query logic using seventeen ICD-9 and OPS item combinations to trace iNPH cases (or insured subjects with a high probability of iNPH). Table $\mathbf{1}$ summarizes the query steps. 
Table 1. Translation of the epidemiological questions into a query logic of operations of ICD and OPS codes.

\begin{tabular}{|c|c|c|}
\hline No. & Epidemiological Question & $\begin{array}{l}\text { Query logic using a logic operation of German- } \\
\text { ICD-9 codes and German OPS codes }\end{array}$ \\
\hline Q1 & How many patients with any type of hydrocephalus underwent surgery in that year? & a) G91* AND 5-023.00; b) G91* AND 5-023.10 \\
\hline Q2 & $\begin{array}{c}\text { How many patients with (idiopathic) normal pressure hydrocephalus underwent surgery in } \\
\text { that year? }\end{array}$ & $\begin{array}{ll}\text { a) G91.2* AND (5-023.00 OR } & 5-023.10) \\
\text { b) G91.20 AND (5-023.00 OR } & 5-023.10)\end{array}$ \\
\hline Q3 & $\begin{array}{l}\text { How many patients with normal pressure hydrocephalus underwent revision surgery in that } \\
\text { year? }\end{array}$ & $\begin{array}{l}\text { a) G91.2* AND 5-023.00 AND 5-024* } \\
\text { b) G91.2* AND 5-023.10 AND 5-024* }\end{array}$ \\
\hline Q4 & $\begin{array}{l}\text { How many patients with normal pressure hydrocephalus underwent revision surgery in that } \\
\text { year, but had undergone shunt implantation in another, earlier year? }\end{array}$ & G91.2* AND 5-024* NOT (5-023.00 OR 5-023.10) \\
\hline Q5 & $\begin{array}{l}\text { How many patients with normal pressure hydrocephalus underwent revision surgery in that } \\
\text { year due to infectious complications? }\end{array}$ & $\begin{array}{c}\text { a) G91.2* AND 5-023.00 AND 5-024* AND } \\
(\mathrm{G} 00 * \text { OR G01* OR G02* OR G03* OR G04* OR } \\
\text { G05* OR G06* OR G07* OR G08*) } \\
\text { b) G91.2* AND 5-023.10 AND 5-024* AND } \\
(\mathrm{G} 00 * \text { OR G01* OR G02* OR G03* OR G04* OR } \\
\text { G05* OR G06* OR G07* OR G08*) }\end{array}$ \\
\hline Q6 & $\begin{array}{l}\text { cross-check: How many patients with normal pressure hydrocephalus underwent revision } \\
\text { surgery within that year due to infectious complications? }\end{array}$ & $\begin{array}{l}\text { a) G91.2* AND 5-023.00 AND 5-024* AND } \\
\text { T85.72 } \\
\text { b) G91.2* AND 5-023.10 AND 5-024* AND } \\
\text { T85.72 }\end{array}$ \\
\hline Q7 & $\begin{array}{l}\text { 2nd cross-check: How many patients with normal pressure hydrocephalus underwent } \\
\text { revision surgery within that year due to infectious complications? }\end{array}$ & $\begin{array}{l}\text { a) G91.2* AND 5-023.00 AND 5-024* AND } \\
\text { G04.9 } \\
\text { b) G91.2* AND 5-023.10 AND 5-024* AND } \\
\text { G04.9 }\end{array}$ \\
\hline Q8 & $\begin{array}{l}\text { How many patients with normal pressure hydrocephalus underwent revision surgery in that } \\
\text { year due to mechanical complications? }\end{array}$ & $\begin{array}{l}\text { a) G91.2* AND 5-023.00 AND 5-024* AND } \\
\text { T85.0 } \\
\text { b) G91.2* AND 5-023.10 AND 5-024* AND } \\
\text { T85.0 }\end{array}$ \\
\hline Q9 & How many NPH patients underwent surgery due to over-drainage complications? & $\begin{array}{l}\text { a) G91.2* AND 5-023.00 AND 5-024* AND } \\
\text { T85.0 AND G97.2 } \\
\text { b) G91.2* AND 5-023.10 AND 5-024* AND } \\
\text { T85.0 AND G97.2 }\end{array}$ \\
\hline Q10 & How many patients with iNPH underwent ICP measurement within a diagnostic pathway? & 5-029.10 AND G91.20 \\
\hline Q11 & $\begin{array}{l}\text { How many patients with iNPH underwent ICP measurement within a diagnostic pathway } \\
\text { and underwent surgery? }\end{array}$ & 5-029.10 AND c AND 5-023.10 \\
\hline Q12 & How many patients with iNPH were coded? & G91.20 \\
\hline Q13 & How many patients were coded with iNPH and Parkinson's disease? & G91.20 AND G20* \\
\hline Q14 & How many patients were coded with iNPH and Alzheimer's disease? & G91.20 AND G30* \\
\hline Q15 & How many patients with iNPH and Parkinson's disease underwent vp shunt surgery? & G91.20 AND G20* AND 5-023.10 \\
\hline Q16 & How many patients with iNPH and Alzheimer's disease underwent vp shunt surgery? & G91.20 AND G30* AND 5-023.10 \\
\hline Q17 & How many patients hydrocephalus underwent endoscopic IIIrd venrticulostomy? & G91* AND 5-022.20 \\
\hline
\end{tabular}

The number of patients meeting the combinations of criteria of the queries Q1 to Q18 were calculated as follows:

\section{Q1 Incidence of Hydrocephalus in Germany}

To calculate the incidence of manifest hydrocephalic diseases in Germany, the number of patients with shunt implantations within the Barmer insurants population was established by a combination of the ICD code G91* (any hydrocephalus) and the OPS code for shunt implantation (ventriculo-atrial [va] shunt 5-023.00, ventriculo-peritoneal [vp] shunt 5-023.10). The incidence was calculated with the absolute number of events and the total number of insurants belonging to the Barmer health insurance company. Knowing the incidence and number of German inhabitants, we estimated the annual number of va and vp shunt implantations for any cause in Germany.

\section{Q2 Incidence of Normal Pressure Hydrocephalus and Idiopathic Normal Pressure Hydrocephalus in Germany}

The incidence of (i)NPH was estimated by combining the diagnoses NPH (ICD G91.2*) or iNPH (ICD G91.20) with shunt surgery, i.e. vp shunt surgery (OPS 5-023.10) OR va shunt surgery (OPS 5-023.00).

\section{Q3, Q4 Complications and revision surgery in patients with NPH}

The number of patients who underwent revision surgery was queried by the combination of the ICD code for iNPH (G91.20) and the OPS codes for shunt implantation and shunt revision (5-023.00 resp. 5-023.10 AND 5-024*). The 
query was split into a) va shunts and b) vp shunts. Q4 traced revision operations that were performed in the year following initial shunt surgery, thus representing late complications.

\section{Q5, Q6, Q7 Infectious complications in patients with NPH}

We employed the codes for iNPH (G91.20), shunt implantation (5-023.00 resp. 5-023.10), shunt revisions (5-024.*) and infections (G00.* - G08.*) to derive the number of shunt revisions due to infectious complications. The results were cross-checked using other code combinations (Table 1).

\section{Q8, Q9 Mechanical complications and over-drainage in patients with NPH}

Mechanical complications were queried by the OPS for any mechanical dysfunction of hydrocephalus shunt valves (T85.0). To calculate the incidence of patients with over-drainage complications, the ICD code G97.2 was added.

\section{Q10, Q11 Diagnostics}

Q10 determined the frequency of ICP measurement for NPH diagnostics. Q11 targeted the number of patients who underwent surgery after being diagnosed with NPH by ICP measurement.

\section{Q12 Prevalence of NPH in Germany}

The prevalence of NPH independently of a procedure was ascertained by the G91.20 code.

\section{Q13, Q14, Q15, Q16 Comorbidity}

Co-morbidities were evaluated using a combined query for patients who were simultaneously coded with NPH and Alzheimer's disease (Q13) or Parkinson's disease (Q14). Q15 and Q16 assessed co-morbidity in patients who underwent vp shunt surgery.

\section{Q18 Endoscopic third ventriculostomy (ETV)}

Q18 was used to calculate the frequency of ETV procedures for any kind of hydrocephalus.

\section{Statistical Analysis}

The prevalence and incidence of iNPH were reported as $n / 100,000$ inhabitants. Since the number of Barmer insurants represent almost one tenth of German population, epidemiological estimates were regarded representative for the entire nation.

This study was exploratory, and no inferential statistics were applied. Presuming a Poisson distribution, 95\% confidence intervals (CI) were calculated for all rate and ratio estimates. STATA 11.2 software was used for all descriptive analyses.

\section{RESULTS}

\section{Incidence}

The results of invidual queries are shown in Tables 2-8.

Table 2. Absolute numbers of va and vp shunts implanted for any indication a) in the insurants of the BARMER GEK health insurance company; b) estimation of total numbers of va and vp shunt operations for Germany; c) calculated incidence of va and vp shunt operations due to any indication per 100.000 inhabitants per year for Germany.

\begin{tabular}{|c|c|c|c|c|c|c|c|c|}
\hline Year & \multicolumn{2}{|c|}{$\begin{array}{c}\text { a) BARMER GEK health } \\
\text { insurance }\end{array}$} & \multicolumn{3}{c|}{ b) Estimation for Germany } & \multicolumn{2}{c|}{$\begin{array}{c}\text { c) Incidence (per 100.000 inhabitants per year in } \\
\text { Germany) with 95\% confidence intervals }\end{array}$} \\
\cline { 2 - 9 } & $\begin{array}{c}\text { insurants } \\
\text { (total) }\end{array}$ & $\begin{array}{c}\text { va shunt } \\
\text { (Q1a) }\end{array}$ & $\begin{array}{c}\text { vp shunt } \\
\text { (Q1b) }\end{array}$ & $\begin{array}{c}\text { Total inhabitants } \\
\text { Germany }\end{array}$ & va shunt & vp shunt & va shunt & vp shunt \\
\hline 2003 & $7,478,603$ & 28 & 300 & $80,493,000$ & 301 & 3229 & $0.37(0.25 ; 0.54)$ & $4.01(3.57 ; 4.49)$ \\
\hline 2004 & $7,259,609$ & 33 & 398 & $81,844,000$ & 372 & 4487 & $0.45(0.32 ; 0.64)$ & $5.48(4.96 ; 6.05)$ \\
\hline 2005 & $7,096,165$ & 50 & 474 & $81,752,000$ & 576 & 5461 & $0.70(0.52 ; 0.93)$ & $6.68(6.09 ; 7.31)$ \\
\hline 2006 & $6,961,988$ & 35 & 487 & $81,802,000$ & 411 & 5722 & $0.50(0.35 ; 0.7)$ & $7.00(6.39 ; 7.64)$ \\
\hline 2007 & $6,883,815$ & 30 & 529 & $82,002,000$ & 357 & 6302 & $0.44(0.29 ; 0.62)$ & $7.68(7.04 ; 8.37)$ \\
\hline 2008 & $6,809,292$ & 20 & 537 & $82,218,000$ & 241 & 6484 & $0.29(0.18 ; 0.45)$ & $7.89(7.23 ; 8.58)$ \\
\hline 2009 & $6,780,370$ & 23 & 555 & $82,315,000$ & 279 & 6738 & $0.34(0.22 ; 0.51)$ & $8.19(7.52 ; 8.9)$ \\
\hline 2010 & $8,531,738$ & 21 & 542 & $82,438,000$ & 203 & 5237 & $0.25(0.15 ; 0.38)$ & $6.35(5.83 ; 6.91)$ \\
\hline
\end{tabular}


(Table 2) contd.....

\begin{tabular}{|c|c|c|c|c|c|c|c|c|}
\hline \multirow[t]{2}{*}{ Year } & \multicolumn{3}{|c|}{$\begin{array}{l}\text { a) BARMER GEK health } \\
\text { insurance }\end{array}$} & \multicolumn{3}{|c|}{ b) Estimation for Germany } & \multicolumn{2}{|c|}{$\begin{array}{l}\text { c) Incidence (per } 100.000 \text { inhabitants per year in } \\
\text { Germany) with } 95 \% \text { confidence intervals }\end{array}$} \\
\hline & \begin{tabular}{|c|} 
insurants \\
(total)
\end{tabular} & $\begin{array}{c}\text { va shunt } \\
\text { (Q1a) }\end{array}$ & $\begin{array}{l}\text { vp shunt } \\
\text { (Q1b) }\end{array}$ & $\begin{array}{c}\text { Total inhabitants } \\
\text { Germany }\end{array}$ & va shunt & vp shunt & va shunt & vp shunt \\
\hline 2011 & $8,615,687$ & 26 & 490 & $82,501,000$ & 249 & 4692 & $0.30(0.2 ; 0.44)$ & $5.69(5.19 ; 6.21)$ \\
\hline 2012 & $8,658,107$ & 34 & 556 & $82,532,000$ & 324 & 5300 & $0.39(0.27 ; 0.55)$ & $6.42(5.9 ; 6.98)$ \\
\hline
\end{tabular}

Altogether, the annual incidence of hydrocephalus treated by shunt surgery was estimated at 6.94 / 100,000 (Table 2). The estimated incidence of iNPH treated by shunt surgery was 1.08 / 100,000 (Table 3, Fig. 1).

Table 3. Total numbers of Barmer patients who underwent shunt surgery for NPH resp. iNPH, calculated incidence and estimated total number for Germany.

\begin{tabular}{|c|c|c|c|c|c|c|}
\hline \multirow{2}{*}{ Year } & \multicolumn{3}{|c|}{ NPH } & \multicolumn{3}{c|}{ iNPH } \\
\cline { 2 - 7 } & nBARMER & incidence & nGermany & nBARMER & incidence & nGermany \\
\hline 2003 & 64 & 0,86 & 689 & 0 & 0,00 & 0 \\
\hline 2004 & 70 & 0,96 & 789 & 31 & 0,43 & 349 \\
\hline 2005 & 115 & 1,62 & 1325 & 64 & 0,90 & 737 \\
\hline 2006 & 141 & 2,03 & 1657 & 86 & 1,24 & 1010 \\
\hline 2007 & 141 & 2,05 & 1680 & 101 & 1,47 & 1203 \\
\hline 2008 & 121 & 1,78 & 1461 & 78 & 1,15 & 942 \\
\hline 2009 & 167 & 2,46 & 2027 & 109 & 1,61 & 1323 \\
\hline 2010 & 163 & 1,91 & 1575 & 117 & 1,37 & 1131 \\
\hline 2011 & 144 & 1,67 & 1379 & 110 & 1,28 & 1053 \\
\hline 2012 & 165 & 1,91 & 1573 & 118 & 1,36 & 1125 \\
\hline mean & 129 & 1,73 & 1416 & 81 & 1,08 & 887 \\
\hline
\end{tabular}

\section{Prevalence}

According to the Barmer data we estimated total numbers of patients with iNPH in Germany between 8609 and 11363 for the last 5 years of the sample period (2008-2012) (Table 7, Fig. 2).

\section{Revision Surgery}

We found a mean incidence of 0.19 / 100,000 of shunt revision surgery within one year after the initial shunt implantation (Table 4). This corresponds to the incidence of early shunt complications. Given the incidence of shunt implantations due to NPH of $1.73 / 100,000$, this means a $10 \%$ revision rate in the first year. The reasons for these revisions also include mechanical and infectious complications.

Table 4. Patients with NPH undergoing revision surgery within the year of implantation, reported for Q3a) va and Q3b) vp shunts and patients with NPH undergoing revision surgery in another year than in the year of implantation independent of the shunt type (Q4).

\begin{tabular}{|c|c|c|c|c|c|c|c|c|c|}
\hline \multirow[t]{3}{*}{ Year } & \multicolumn{6}{|c|}{$\begin{array}{c}\text { How many patients with normal pressure hydrocephalus underwent revision } \\
\text { surgery in that year? }\end{array}$} & \multirow{2}{*}{\multicolumn{3}{|c|}{$\begin{array}{l}\text { How many patients with NPH underwent } \\
\text { revision surgery in that year but had } \\
\text { undergone shunt implantation in another, } \\
\text { earlier year? } \\
\text { Q4 (va + vp shunts) }\end{array}$}} \\
\hline & \multicolumn{3}{|c|}{ Q3a (va shunts) } & \multicolumn{3}{|c|}{ Q3b (vp shunts) } & & & \\
\hline & nBARMER & incidence & nGermany & nBARMER & incidence & nGermany & nBARMER & incidence & nGermany \\
\hline 2003 & 0 & 0,00 & 0 & 6 & 0,08 & 65 & 9 & 0,12 & 97 \\
\hline 2004 & 0 & 0,00 & 0 & 4 & 0,06 & 45 & 11 & 0,15 & 124 \\
\hline 2005 & 3 & 0,04 & 35 & 16 & 0,23 & 184 & 17 & 0,24 & 196 \\
\hline 2006 & 4 & 0,06 & 47 & 19 & 0,27 & 223 & 16 & 0,23 & 188 \\
\hline 2007 & 1 & 0,01 & 12 & 11 & 0,16 & 131 & 30 & 0,44 & 357 \\
\hline 2008 & 1 & 0,01 & 12 & 17 & 0,25 & 205 & 25 & 0,37 & 302 \\
\hline 2009 & 1 & 0,01 & 12 & 15 & 0,22 & 182 & 27 & 0,40 & 328 \\
\hline 2010 & 1 & 0,01 & 10 & 20 & 0,23 & 193 & 24 & 0,28 & 232 \\
\hline 2011 & 1 & 0,01 & 10 & 18 & 0,21 & 172 & 31 & 0,36 & 297 \\
\hline 2012 & 1 & 0,01 & 10 & 15 & 0,17 & 143 & 21 & 0,24 & 200 \\
\hline mean & 1 & 0,02 & 15 & 14 & 0,19 & 154 & 21 & 0,28 & 232 \\
\hline
\end{tabular}




\section{Complications}

Among the annual mean number of $129 \mathrm{NPH}$ patients in the Barmer population undergoing surgery, the mean number of infectious complications according to different definitions ranged from 0 to 1 per year (Table 5). Also, the frequency of reported over-drainage events was extremely low, suggesting some underreporting. It is likely that shunt infections and mechanical complications were frequently not coded correctly since only the general OPS code for shunt revision is relevant for reimbursement under German Diagnosis Related Group (DRG) conditions (Tables 5, 6).

Table 5. Shunt revision due to infectious complications. nB number of patients within the BARMER population, inc. incidence, nG estimated number of patients in Germany.

\begin{tabular}{|c|c|c|c|c|c|c|c|c|c|c|c|c|c|c|c|c|c|c|}
\hline & \multicolumn{3}{|c|}{ Q5a } & \multicolumn{3}{|c|}{ Q5b } & \multicolumn{3}{|c|}{ Q6a } & \multicolumn{3}{|c|}{ Q6b } & \multicolumn{3}{|c|}{ Q7a } & \multicolumn{3}{|c|}{ Q7b } \\
\hline Year & nB & inc. & $\overline{\mathrm{nG}}$ & $\mathrm{nB}$ & inc. & nG & nB & inc. & nG & nB & inc. & nG & $\mathrm{nB}$ & inc. & nG & nB & inc. & $\mathrm{nG}$ \\
\hline 2003 & 0 & 0,00 & 0 & 0 & 0,00 & 0 & 0 & 0,00 & 0 & 0 & 0,00 & 0 & 0 & 0,00 & 0 & 0 & 0,00 & 0 \\
\hline 2004 & 0 & 0,00 & 0 & 0 & 0,00 & 0 & 0 & 0,00 & 0 & 0 & 0,00 & 0 & 0 & 0,00 & 0 & 0 & 0,00 & 0 \\
\hline 2005 & 0 & 0,00 & 0 & 1 & 0,01 & 12 & 0 & 0,00 & 0 & 0 & 0,00 & 0 & 0 & 0,00 & 0 & 0 & 0,00 & 0 \\
\hline 2006 & 2 & 0,03 & 23 & 1 & 0,01 & 12 & 0 & 0,00 & 0 & 0 & 0,00 & 0 & 1 & 0,01 & 12 & 0 & 0,00 & 0 \\
\hline 2007 & 0 & 0,00 & 0 & 0 & 0,00 & 0 & 0 & 0,00 & 0 & 0 & 0,00 & 0 & 0 & 0,00 & 0 & 0 & 0,00 & 0 \\
\hline 2008 & 0 & 0,00 & 0 & 1 & 0,01 & 12 & 0 & 0,00 & 0 & 0 & 0,00 & 0 & 0 & 0,00 & 0 & 0 & 0,00 & 0 \\
\hline 2009 & 1 & 0,01 & 12 & 0 & 0,00 & 0 & 0 & 0,00 & 0 & 0 & 0,00 & 0 & 1 & 0,01 & 12 & 0 & 0,00 & 0 \\
\hline 2010 & 0 & 0,00 & 0 & 3 & 0,04 & 29 & 0 & 0,00 & 0 & 0 & 0,00 & 0 & 0 & 0,00 & 0 & 0 & 0,00 & 0 \\
\hline 2011 & 1 & 0,01 & 10 & 1 & 0,01 & 10 & 0 & 0,00 & 0 & 0 & 0,00 & 0 & 0 & 0,00 & 0 & 0 & 0,00 & 0 \\
\hline 2012 & 0 & 0,00 & 0 & 2 & 0,02 & 19 & 0 & 0,00 & 0 & 1 & 0,01 & 12 & 0 & 0,00 & 0 & 1 & 0,01 & 12 \\
\hline mean & 0,4 & 0,01 & 5 & 0,9 & 0,01 & 9 & 0 & 0,00 & 0 & 0,1 & 0,00 & 1 & 0,2 & 0,00 & 2 & 0,1 & 0,00 & 1 \\
\hline
\end{tabular}

Table 6. Frequencies of mechanical complications in NPH patients as coded for the Barmer population.

\begin{tabular}{|c|c|c|c|c|c|c|c|c|c|c|c|c|}
\hline & Q8a & & & Q8b & & & Q9a & & & Q9b & inc. & nG \\
\hline Year & nB & inc. & nG & nB & inc. & nG & nB & inc. & nG & nB & ince \\
\hline 2003 & 0 & 0,00 & 0 & 3 & 0,04 & 32 & 0 & 0,00 & 0 & 0 & 0,00 & 0 \\
\hline 2004 & 0 & 0,00 & 0 & 1 & 0,01 & 11 & 0 & 0,00 & 0 & 0 & 0,00 & 0 \\
\hline 2005 & 2 & 0,03 & 23 & 5 & 0,07 & 58 & 0 & 0,00 & 0 & 0 & 0,00 & 0 \\
\hline 2006 & 1 & 0,01 & 12 & 10 & 0,14 & 117 & 0 & 0,00 & 0 & 0 & 0,00 & 0 \\
\hline 2007 & 0 & 0,00 & 0 & 5 & 0,07 & 60 & 0 & 0,00 & 0 & 1 & 0,01 & 12 \\
\hline 2008 & 0 & 0,00 & 0 & 8 & 0,12 & 97 & 0 & 0,00 & 0 & 1 & 0,01 & 12 \\
\hline 2009 & 0 & 0,00 & 0 & 5 & 0,07 & 61 & 0 & 0,00 & 0 & 0 & 0,00 & 0 \\
\hline 2010 & 1 & 0,01 & 10 & 10 & 0,12 & 97 & 0 & 0,00 & 0 & 0 & 0,00 & 0 \\
\hline 2011 & 0 & 0,00 & 0 & 8 & 0,09 & 77 & 0 & 0,00 & 0 & 0 & 0,00 & 0 \\
\hline 2012 & 1 & 0,01 & 10 & 7 & 0,08 & 67 & 0 & 0,00 & 0 & 0 & 0,00 & 0 \\
\hline mean & 0,5 & 0,01 & 5 & 6,2 & 0,08 & 68 & 0 & 0,00 & 0 & 0,2 & 0,00 & 2 \\
\hline
\end{tabular}

\section{Endoscopic Third Ventriculostomy (ETV)}

The mean annual number of ETV procedures for all types of hydrocephalus ranged from 51 to 487 during the 10 year observational period (Fig. 3).

\section{DISCUSSION}

This study is the first nationwide, population-based investigation on the epidemiology of idiopathic normal pressure hydrocephalus (iNPH) in Germany. It is based on a representative sample of 7.5 million patients covered by the Barmer health insurance company. The incidence of iNPH calculated in this study resembled to that reported in ten previous investigations. These studies included between 233 and 4.6 million subjects and suggested annual incidence rates between 1.09 and $5.5 / 100,000$.

The key problem in estimating the incidence of iNPH on a population-based level is the lack of accepted and accurate diagnostic test criteria, introducing misclassification bias. The aggregated sample employed in this analysis comprised 1) patients meeting clinical criteria, 2) patients who underwent invasive diagnostics, 3) patients who underwent shunt surgery, 4) patients who became shunt responders after surgery and 4) patients with unspecific coding 
(e.g., G91.9 for NPH rather than G91.2 for iNPH).

The cohort investigated here resembles a population that may have included a large number of false positives and may have excluded false negatives. Different definitions of iNPH are a likely source for the variation in incidence rates as shown in different studies (Table 9).

The low incidence of infectious and mechanical complications observed in this study differs markedly from literature estimates which range from 3 to $12 \%(4 ; 14-17)$. We recently found over-drainage rates of $30 \%$ with conventional programmable valves in a randomised multicentre study (6).

Available prevalence data were often derived from selected populations such as inhabitants of nursing homes and are therefore not comparable to the present results.

Also, the risk of selection bias may be higher in smaller populations, we could not substantiate a correlation between the reported prevalence data and the population size of the studies (Table 8). So, the prevalence reported by the different authors seems to be not very stable.

Our findings suggest a 10times higher rate of ETV in all hydrocephalus cases compared to iNPH. This is in contrast to another recent population-based study on 12,845 and 652 (20:1) discharges after ETV and VPS recorded between 2007 and 2010 (18).

Table 7. Prevalence of NPH.

\begin{tabular}{|c|c|c|c|c|c|}
\hline Year & Insurants (total) & Inhabitants Germany & nBARMER & Prevalence (95\% CI's) & nGermany \\
\hline 2003 & 7.478 .603 & 80.493 .000 & 0 & $0,00 \%$ & 0 \\
\hline 2004 & 7.259 .609 & 81.844 .000 & 368 & $0,01 \%$ & 4148 \\
\hline 2005 & 7.096 .165 & 81.752 .000 & 477 & $0,01 \%$ & 5495 \\
\hline 2006 & 6.961 .988 & 81.802 .000 & 569 & $0,01 \%$ & 6685 \\
\hline 2007 & 6.883 .815 & 82.002 .000 & 703 & $0,01 \%$ & 8374 \\
\hline 2008 & 6.809 .292 & 82.218 .000 & 733 & $0,01 \%$ & 8851 \\
\hline 2009 & 6.780 .370 & 82.315 .000 & 936 & $0,01 \%$ & 11363 \\
\hline 2010 & 8.531 .738 & 82.438 .000 & 961 & $0,01 \%$ & 9286 \\
\hline 2011 & 8.615 .687 & 82.501 .000 & 899 & $0,01 \%$ & 8609 \\
\hline 2012 & 8.658 .107 & 82.532 .000 & 1000 & $0,01 \%$ & 9532 \\
\hline
\end{tabular}

Table 8. Frequency of co-morbidities (Alzheimer's disease Q13 and Parkinson's disease Q14) coded together with NPH and frequency of these co-morbidities among shunted patients $(\mathrm{Q} 15, \mathrm{Q16})$.

\begin{tabular}{|c|c|c|c|c|c|c|c|c|c|c|c|c|}
\hline & Q13 & & & Q14 & & & Q15 & & & Q16 & & \\
\hline Year & nB & inc. & nG & nB & inc. & nG & nB & inc. & nG & nB & inc. & nG \\
\hline $\mathbf{2 0 0 3}$ & 0 & 0,00 & 0 & 0 & 0,00 & 0 & 0 & 0,00 & 0 & 0 & 0,00 & 0 \\
\hline $\mathbf{2 0 0 4}$ & 1 & 0,01 & 11 & 0 & 0,00 & 0 & 1 & 0,01 & 11 & 0 & 0,00 & 0 \\
\hline $\mathbf{2 0 0 5}$ & 4 & 0,06 & 46 & 1 & 0,01 & 12 & 4 & 0,06 & 46 & 1 & 0,01 & 12 \\
\hline $\mathbf{2 0 0 6}$ & 11 & 0,16 & 129 & 1 & 0,01 & 12 & 6 & 0,09 & 70 & 1 & 0,01 & 12 \\
\hline $\mathbf{2 0 0 7}$ & 9 & 0,13 & 107 & 1 & 0,01 & 12 & 7 & 0,10 & 83 & 1 & 0,01 & 12 \\
\hline $\mathbf{2 0 0 8}$ & 5 & 0,07 & 60 & 1 & 0,01 & 12 & 4 & 0,06 & 48 & 1 & 0,01 & 12 \\
\hline $\mathbf{2 0 0 9}$ & 9 & 0,13 & 109 & 2 & 0,03 & 24 & 8 & 0,12 & 97 & 2 & 0,03 & 24 \\
\hline $\mathbf{2 0 1 0}$ & 8 & 0,09 & 77 & 4 & 0,05 & 39 & 5 & 0,06 & 48 & 3 & 0,04 & 29 \\
\hline $\mathbf{2 0 1 1}$ & 7 & 0,08 & 67 & 0 & 0,00 & 0 & 5 & 0,06 & 48 & 0 & 0,00 & 0 \\
\hline $\mathbf{2 0 1 2}$ & 6 & 0,07 & 57 & 1 & 0,01 & 10 & 5 & 0,06 & 48 & 1 & 0,01 & 10 \\
\hline
\end{tabular}

Table 9. Compilation of all reported epidemiological data concerning the prevalence and incidence of iNPH in the literature [3 - 13].

\begin{tabular}{|c|c|c|c|c|}
\hline Author & $\begin{array}{c}\text { Year of } \\
\text { publication }\end{array}$ & Population (n) / setting & Study design & Epidemiological data \\
\hline $\begin{array}{c}\text { Lemcke, } \\
\text { Stockhammer, } \\
\begin{array}{c}\text { Stengl, Rohde, } \\
\text { Meier }\end{array}\end{array}$ & 2016 & $\begin{array}{c}7.507 .537( \pm 784.241) \text { insurants of the } \\
\text { Bamer health insurance company }\end{array}$ & $\begin{array}{c}\text { Retrospective query of diagnosis } \\
\text { and procedural coding }\end{array}$ & $\begin{array}{c}\text { Incidence 2012: } \\
1.36 / 100.000 / \text { year }\end{array}$ \\
\hline
\end{tabular}




\begin{tabular}{|c|c|c|c|c|}
\hline Author & $\begin{array}{c}\text { Year of } \\
\text { publication }\end{array}$ & Population (n) / setting & Study design & Epidemiological data \\
\hline Jaraj et al. & 2014 & $\begin{array}{c}1238 \text { patients }>70 \text { years between } 1986 \\
\text { and } 2000\end{array}$ & $\begin{array}{c}\text { Prospective trial with CT scan and } \\
\text { neuropsychological examnination }\end{array}$ & $\begin{array}{c}\text { prevalence of probable iNPH in } \\
\text { patients between } 70-79 \text { years } \\
0.2 \%,>80 \text { years } 5.9 \%\end{array}$ \\
\hline Muangpaisan et al. & 2012 & $\begin{array}{l}233 \text { patients of the outpatient geriatric } \\
\text { clinic at Siriraj Hospital, Bangkok, } \\
\text { Thailand }\end{array}$ & $\begin{array}{l}\text { Retrospective query of medical } \\
\text { records }\end{array}$ & Prevalance $0.9 \%$ \\
\hline $\begin{array}{l}\text { Klassen and } \\
\text { Ahlskog }\end{array}$ & 2011 & $\begin{array}{c}124,277 \text { inhabitants of Ol- } \\
\text { msted County, Minnesota, USA }\end{array}$ & $\begin{array}{l}\text { Retrospective query of medical } \\
\text { records }\end{array}$ & Incidence $1.19 / 100,000 /$ year \\
\hline Cabral et al. & 2011 & $\begin{array}{c}563 \text { cases with neuropathology of } \\
\text { dementia } \\
\text { illness at autopsy in the Sun Health } \\
\text { Research Institute Brain Donation } \\
\text { Program database, } \\
\text { The Cleo Roberts Center for Clinical } \\
\text { Research, Banner-Sun Health Research } \\
\text { Institute, Sun City, AZ, USA }\end{array}$ & $\begin{array}{l}\text { Retrospective query of medical } \\
\text { records }\end{array}$ & $\begin{array}{c}\text { Prevalence } 1.6 \% \\
\text { (of patients with dementia) }\end{array}$ \\
\hline Brean, Eide et al. & 2009 & $4,644,761$ inhabitants of Norway (2006) & $\begin{array}{l}\text { Retrospective query of medical } \\
\text { records }\end{array}$ & $\begin{array}{c}1.09 / 100,000 / \text { year } \\
(>65 \text { yrs. } 30.200,000 / \text { year })\end{array}$ \\
\hline Tanaka et al. & 2009 & $\begin{array}{c}567 \text { randomly selected patients out of } \\
1,654 \text { inhabitants of Tajiri, } \\
\text { Japan } \geq 65 \text { years (Osaki-Tajiri project) }\end{array}$ & $\begin{array}{l}\text { Retrospective query of medical } \\
\text { records }\end{array}$ & $\begin{array}{l}\text { Prevalence of possible iNPH in } \\
\text { patients } \geq 65 \text { years } 1.4 \%\end{array}$ \\
\hline Brean and Eide & 2008 & $\begin{array}{c}220,000 \text { inhabitants of the south-eastern } \\
\text { part of Norway }\end{array}$ & $\begin{array}{l}\text { Prospective population based } \\
\text { study }\end{array}$ & Incidence 5.5/100,000/year \\
\hline Hiraoka et al. & 2008 & $\begin{array}{c}170 \text { randomly selected residents over } 65 \\
\text { years out of } 2516 \text { elderly inhabitants of } \\
\text { the town Tajiri (Miyagi, Japan) }\end{array}$ & $\begin{array}{l}\text { Retrospective query of medical } \\
\text { records }\end{array}$ & $\begin{array}{c}\text { Prevalence } 2.9 \% \text { patients } \geq 65 \\
\text { yrs. }\end{array}$ \\
\hline Marmarou et al. & 2007 & $\begin{array}{l}147 \text { patient in a retrospective chart } \\
\text { analysis using the medical records } \\
\text { from four nursing homes }\end{array}$ & $\begin{array}{l}\text { Retrospective query of medical } \\
\text { records }\end{array}$ & $\begin{array}{l}\text { Prevalence } 9 \text { to } 14 \% \text { (depending } \\
\text { on the diagnostic criteria) of the } \\
\text { inhabitants of the nursing homes }\end{array}$ \\
\hline Tisell et al. & 2005 & $\begin{array}{l}891 \text { patients who underwent surgery for } \\
\text { hydrocephalus in one the six university } \\
\text { hospitals in Sweden during 1996-1998 }\end{array}$ & $\begin{array}{l}\text { Retrospective query of medical } \\
\text { records }\end{array}$ & $\begin{array}{c}1.6 / 100.000 / \text { year }(47 \% \text { of } \\
3.4 / 100.000 / \text { year })\end{array}$ \\
\hline Trenkwalder & 1995 & $\begin{array}{l}982 \text { participants of a } \\
\text { door-to-door survey in the Starnberg } \\
\text { community, Bavaria, Germany }\end{array}$ & $\begin{array}{l}\text { Prospective population based } \\
\text { study }\end{array}$ & $\begin{array}{c}\text { Prevalence } 0.41 \% \text { in patients } \geq \\
65 \text { yrs. }\end{array}$ \\
\hline
\end{tabular}

\section{CONCLUSION}

Based on the analysis of ca. 7.5 million insurants of the Barmer health insurance we estimated an incidence of iNPH for Germany of 1.08 / 100,000 / year.

\section{CONFLICT OF INTEREST}

The authors declare that they have no competing interests.

\section{ACKNOWLEDGEMENTS}

Data from the Barmer health insurance company provided by the Barmer Berlin / Brandenburg bureau form the basis of this study. We like to thank the bureau for allowing us access to these data. However, the interpretation and conclusions presented in this manuscript do not necessarily represent the views of Barmer.

\section{REFERENCES}

[1] Greitz D. Cerebrospinal fluid circulation and associated intracranial dynamics. A radiologic investigation using MR imaging and radionuclide cisternography. Acta Radiol Suppl 1993; 386: 1-23.

[PMID: 8517189]

[2] Greitz D, Hannerz J, Rähn T, Bolander H, Ericsson A. MR imaging of cerebrospinal fluid dynamics in health and disease. On the vascular pathogenesis of communicating hydrocephalus and benign intracranial hypertension. Acta Radiol 1994; 35(3): 204-11.

[PMID: 8192953]

[3] Brean A, Fredø HL, Sollid S, Müller T, Sundstrøm T, Eide PK. Five-year incidence of surgery for idiopathic normal pressure hydrocephalus in Norway. Acta Neurol Scand 2009; 120(5): 314-6. 
[http://dx.doi.org/10.1111/j.1600-0404.2009.01250.x] [PMID: 19832773]

[4] Trenkwalder C, Schwarz J, Gebhard J, et al. Starnberg trial on epidemiology of Parkinsonism and hypertension in the elderly. Prevalence of Parkinson's disease and related disorders assessed by a door-to-door survey of inhabitants older than 65 years. Arch Neurol 1995; 52(10): 1017-22.

[http://dx.doi.org/10.1001/archneur.1995.00540340109020] [PMID: 7575219]

[5] Muangpaisan W, Petcharat C, Srinonprasert V. Prevalence of potentially reversible conditions in dementia and mild cognitive impairment in a geriatric clinic. Geriatr Gerontol Int 2012; 12(1): 59-64. [http://dx.doi.org/10.1111/j.1447-0594.2011.00728.x] [PMID: 21794050]

[6] Klassen BT, Ahlskog JE. Normal pressure hydrocephalus: how often does the diagnosis hold water? Neurology 2011; 77(12): 1119-25. [http://dx.doi.org/10.1212/WNL.0b013e31822f02f5] [PMID: 21849644]

[7] Cabral D, Beach TG, Vedders L, et al. Frequency of Alzheimer's disease pathology at autopsy in patients with clinical normal pressure hydrocephalus. Alzheimers Dement 2011; 7(5): 509-13. [http://dx.doi.org/10.1016/j.jalz.2010.12.008]

[8] Brean A, Eide PK. Prevalence of probable idiopathic normal pressure hydrocephalus in a Norwegian population. Acta Neurol Scand 2008; 118(1): 48-53.

[http://dx.doi.org/10.1111/j.1600-0404.2007.00982.x] [PMID: 18205881]

[9] Tanaka N, Yamaguchi S, Ishikawa H, Ishii H, Meguro K. Prevalence of possible idiopathic normal-pressure hydrocephalus in Japan: the Osaki-Tajiri project. Neuroepidemiology 2009; 32(3): 171-5. [http://dx.doi.org/10.1159/000186501] [PMID: 19096225]

[10] Hiraoka K, Meguro K, Mori E. Prevalence of idiopathic normal-pressure hydrocephalus in the elderly population of a Japanese rural community. Neurol Med Chir (Tokyo) 2008; 48(5): 197-9. [http://dx.doi.org/10.2176/nmc.48.197] [PMID: 18497491]

[11] Marmarou A, Young HF, Aygok GA. Estimated incidence of normal pressure hydrocephalus and shunt outcome in patients residing in assisted-living and extended-care facilities. Neurosurg Focus 2007; 22(4): E1. [http://dx.doi.org/10.3171/foc.2007.22.4.2] [PMID: 17613187]

[12] Tisell M, Höglund M, Wikkelsø C. National and regional incidence of surgery for adult hydrocephalus in Sweden. Acta Neurol Scand 2005; 112(2): $72-5$. [http://dx.doi.org/10.1111/j.1600-0404.2005.00451.x] [PMID: 16008530]

[13] Jaraj D, Rabiei K, Marlow T, Jensen C, Skoog I, Wikkelsø C. Prevalence of idiopathic normal-pressure hydrocephalus. Neurology 2014; 82(16): 1449-54.

[http://dx.doi.org/10.1212/WNL.0000000000000342] [PMID: 24682964]

(C) Lemcke et al.; Licensee Bentham Open.

This is an open access article licensed under the terms of the Creative Commons Attribution-Non-Commercial 4.0 International Public License (CC BY-NC 4.0) (https://creativecommons.org/licenses/by-nc/4.0/legalcode), which permits unrestricted, non-commercial use, distribution and reproduction in any medium, provided the work is properly cited. 